\title{
Growth and Yield Performances of Roselle (Hibiscus sabdariffa L.) to Intercropping Practices: A Review
}

\author{
Dejene Tadesse Banjaw* Habitamu Gudisa Megersa Dadi Tolessa Lema \\ Ethiopian Institute of Agricultural Research, Wondo Genet Agricultural Research Center, P.O box 198, \\ Shashamane, Ethiopia
}

\begin{abstract}
Roselle is one of the medicinal plants in the world. Roselle production practice varies from one region to the other and according to the varieties and purpose of production. Hence, in order to enhance production and productivity of Roselle, growers have to be aware of the production possibilities. A world wide Roselle production possibility under intercropping practices has been reviewed for further dissemination of the information. Over all, attention should be given to selection of appropriate Roselle variety and component crop, as well as their temporal and spatial arrangements in intercropping system.
\end{abstract}

Keywords: Intercropping, Medicinal plant, Roselle

DOI: $10.7176 / \mathrm{ALST} / 84-01$

Publication date: December $31^{\text {st }} 2020$

\section{INTRODUCTION}

Roselle (Hibiscus sabdariffa L.) is annual shrub plant that belongs to family Malvaceae. It is medicinal plant that widely grown in tropical and subtropical regions of the world (Plotto et al., 2004). In addition to its health benefit, roselle has industrial and nutritional values (Mahadevan and Kamboj, 2009). Different studies indicated that intercropping influenced crops growth parameters as well as yield and yield components, including roselle. The differences in growth and yield performances of crops in intercropping and pure stand might have been resulted from variations in crops densities (Mehdi et al., 2015), spatial arrangements (Zhang et al., 2015), and crop selection (Pushpa et al., 2017). Moreover, growers practice intercropping for better intercrops yield and monetary advantage by considering crop morphology, growth duration, and management practices (Lithourgidis et al., 2011). As different scholars indicated that, the intercropping performances of roselle in intercropping system have been reviewed and presented as follow.

Intercropping roselle with Aloe Vera in replacement series method showed significant variation in roselle plant dry weight, stem diameter, number of capsule per plant, 100 seed weight, economic yield, but did not affect its plant height (Mehdi et al., 2015). According to the report, a combination of $25 \%$ roselle with $75 \%$ Aloe Vera resulted in an increase in stem diameter $(23.3 \mathrm{~mm})$, a number of capsules per plant (364.5), and roselle economic yield (3.9 ton/hectare) as compared to the corresponding values in roselle sole cropping. However, roselle sole cropping was high in stem diameter (15.6), capsule dry weight (26.5 ton/hectare), and harvest index $(0.06 \%)$. The higher the harvest index at sole cropping indicated the higher roselle economic yield as compared to the yield obtained at the intercropping. Furthermore, in their triple intercropping studies, Rigi et al. (2017) have reported significant variation in roselle yield from which maximum boll wet weight was obtained from $60 \%$ roselle $+20 \%$ peanut $+20 \%$ Aloe Vera crop combinations next to sole roselle cropping. According to Fadi and Gebauer (2004), roselle plant height $(63.7 \mathrm{~cm})$, number of leaves per plant (40.7), number of capsule per plant (26.3), and yield were significantly reduced in intercropping with Acacia senegal in Agroforesty system as compared to roselle sole cropping. On the contrary, roselle-cowpea intercropping resulted in significant increase in the number of roselle fruits per plant and dry sepals yield per plant compared with sole roselle planting system (Gendy et al., 2017). This might be due to the positive contributions of the cowpea in contributing nitrogen during the intercropping. Besides, Pushpa et al. (2017) did concluded that intercropping influenced growth and yield of roselle as significantly shorter plant height was obtained from sole cropping $(135.7 \mathrm{~cm})$ than both roselle-pigeon pea $(144.9 \mathrm{~cm})$ and roselle-castor $(147.6 \mathrm{~cm})$ intercropping. The higher roselle plant height obtained at intercropping practices might be due to light competition. However, the authors have also indicated that, number of branches per plant, plant spread, leaf dry weight, seed yield, and fresh and dry calyx yield of roselle were significantly reduced in intercropping. This implied as there were higher competitions for other growth resources than for sun light in intercropping than sole cropping. Egbutah et al. (2015) summarized that variations in growth and yield of roselle were observed in intercropping with cowpea and with groundnut. According to the report, higher significant results of 100 seed weight (3.51g and 3.86g), number of pods per plant (23.19 and 22.97) and dry calyx yield per hectare $(84.32 \mathrm{~kg}$ and $92.04 \mathrm{~kg}$ ) were obtained from roselle-cowpea and roselle groundnut intercropping systems, respectively. However, seed yield per plant (9.64g), number of seeds per pod (15.72) and harvest index (4.93\%) recorded from sole roselle cropping were not significantly varied from roselle-cowpea intercropping but varied from those obtained from roselle-groundnut intercropping, except harvest index. 


\section{CONCLUSION}

Therefore, from the above findings, it is clear that roselle growth and yield performances vary in an intercropping system. However, for a better growth and yield of roselle in intercropping system, more attention has to be given to the purpose of intercropping, selection of appropriate roselle variety and component crop, as well as their temporal and spatial arrangements.

\section{REFERENCES}

Egbutah, E.U., Obasi, M.M., Kalu, B.A. and Aguoru, C.U., 2015. Correlation among seed yield and yield attributes in Roselle (Hibiscus sabdariffa L.) as influenced by previous intercrop and nitrogen fertilizer. Journal of Agriculture and Food Science. 3(3): 59-64.

Fadi, K.E.M. and Gebauer,J., 2004. Crop Performance and Yield of Groundnut, Sesame and Roselle in an Agroforesty Cropping System with Acacia senegal in North Kordofan (Sudan). Journal of Agriculture and Rural Development in the Tropics and Subtropics. 105(2):149-154.

Gendy, A.S.H., Nosir, W.S. and Nawar, D.A.R., 2017. Evaluation of Competitive Indices between Roselle and Cowpea as Influenced By Intercropping System and Bio-Fertilization Type. Middle East Journal of Agriculture. 6(1): 199-207.

Lithourgidis, A.S., Dordas, C.A., Damalas, C.A. and Vlachostergios, D., 2011. Annual intercrops: an alternative pathway for sustainable agriculture. Australian journal of crop

Mahadevan, N. and Kamboj, P., 2009. Hibiscus sabdariffa Linn: an overview. Natural Product Radiance. 8(1): $77-83$

Mehdi, D., Turan, N. and Issa, K., 2015. Evaluation of aloe Vera intercropping on quantitative and qualitative characteristics of Roselle. Bulgarian Journal of Agricultural Science. 21(4): 779-783.

Plotto, A., Mazaud, F., Röttger, A. and Steffel, K., 2004. Hibiscus: Post-production management for improved market access organization. Food and Agriculture Organization of the United Nations (FAO), AGST. Rome. pp1-14.

Pushpa, T.N., Umesha, K., Vasundhara, M., Ramachandrappa, B.K., Sreeramu, B.S. and Srikantaprasad, D., 2017. Intercropping of Roselle with Red Gram and Nipped Castor is Beneficial to Dry Land Farmer. International Journal of Current Microbiology and Applied Science. 6(9): 2179-2188.

Rigi, K., Mousavinik, S.M., Dahmardeh, M., and Khammari, I., 2017. Evaluation of methanol spraying on yield components of triple intercropping of Roselle, peanut, and Aloe Vera. International Journal of Agriculture and Bioscience. 6(1): 71-75.

Zhang, Y, Liu J, Zhang J, Liu, H, Liu, S, Zhai, L., 2015. Row Ratios of Intercropping Maize and Soybean Can Affect Agronomic Efficiency of the System and Subsequent Wheat. PLOS ONE. 10(6): 1-16 